引用格式:杨柳,朱玉春,任洋. 社会信任、组织支持对农户参与小农水管护绩效的影响[J]. 资源科学, 2018,40(6): 1230-1245. [Yang L, Zhu Y C, Ren Y. Influence of social trust and organizational support on the performance of farmers' participation in the management and maintenance of small-scale farmland water conservancy[J]. Resources Science, 2018,40(6) : 1230-1245.] DOI :10.18402/resci.2018.06.13

\title{
社会信任、组织支持对农户参与 小农水管护绩效的影响
}

\author{
杨 柳, 朱玉春, 任 洋
}

(西北农林科技大学经济管理学院,杨凌 712100)

\begin{abstract}
摘 要: 由于政府主管的小农水治理模式难以充分满足农户农业生产经营的现实需求,农户参与管护成为突 破小农水治理困境的关键。在 IAD 框架基础上,利用内蒙古和宁夏 774 份微观农户调研数据,运用 Ordered Probit 模型, 探讨了社会信任、组织支持对农户参与小农水管护绩效的影响。结果表明: (1) 社会信任与组织支持均显著正 向影响农户参与小农水管护绩效,该结论在剔除老年人样本的情况下仍然成立; 2 组织支持能增强社会信任对管 护绩效的积极作用; (3) 组织支持通过影响农户对村干部和管护制度的认可这两条渠道来发挥其对管护绩效的影响 作用。这表明, 促进农户之间的沟通交流从而提高彼此之间的信任感, 并在此基础上增强村组织对农户的支持力 度,能有效提升农户参与小农水管护绩效,对破解小农水自主治理困境具有借鉴意义。
\end{abstract}

关键词: 社会信任;组织支持;小农水; 管护绩效; Ordered Probit模型;内蒙古;宁夏

DOI :10.18402/resci.2018.06.13

\section{1 引言}

小型农田水利设施( 以下简称“小农水”) 的有 效供给既是增强农业物质装备和提升农业可持续 发展能力的关键途径, 亦是保障国家粮食安全的重 要支撑 ${ }^{[1]}$ 。“十二五”以来, 国家加大了农村基础设施 的建设力度, 小农水的供给水平得到了有效提升。 但由于“重建轻管”或“只建不管”等现象的存在, 很 多灌溉设施并没有充分发挥其运营目标,有些甚至 在建成之后很快“㿈疾”, 究其原因, 主要是未有效 解决管护问题。而解决这一问题的关键在于用水 者的参与,即农户参与小农水管护 ${ }^{[2,3]}$ 。由于政府自 上而下的治理机制难以有效对接农户的实际需求, 单靠增加政府投资不足以有效提升小农水治理绩 效, 农户的积极参与是小农水有效供给过程中必不 可少的环节。但是, 小农水的公共产品属性与农户 家庭生产经营的私人产品属性冲突, 以及管理机制
不完善、维护责任不明晰等问题的存在,大大削弱 了农户参与管护的积极性。同时,忽视不同社会信 任水平农户在参与小农水管护方面的异质性,以及 不同组织支持在农户参与管护方面作用的差异, 又 导致农户参与管护路径发生偏差, 进一步降低了农 户的心理预期和个人贡献,其管护绩效亟待改进。

理论上,农户参与小农水管护是以地域为基础 的众多农户个体自主选择参与从而实现自主治理 的过程。由于农户个体的理性会诱发村庄集体的 非理性,农户参与小农水管护绩效难以达到最优, 而社会信任和组织支持为优化这一绩效提供了新 的思路 ${ }^{[4]}$ 。一方面,社会信任能有效增强合作凝聚 力, 通过建立合作机制和内在约束机制弱化农户在 参与管护时的搭便车心理和行为,增强农户之间的 管护合作 ${ }^{[5]}$ 。另一方面, 组织支持制约着农户参与 管护互惠心理契约的达成,能够增强农户对组织的

收稿日期: 2017-07-19, 修订日期: 2017-10-25

基金项目 :国家自然科学基金项目(71273210;71773092); 陕西高校人文社会科学青年英才支持计划(陕教高(2015)16号)。

作者简介:杨柳,女, 河南安阳人,博士生, 主要研究方向为区域经济发展。E-mail:yangliu6661@126.com

通讯作者:朱玉春,E-mail:zhuyuchun321@126.com

http://www.resci.cn 
认可, 从而在管护激励中做出积极的行为响应, 最 终影响小农水管护绩效 ${ }^{[6]}$ 。那么, 社会信任和组织 支持对农户参与小农水管护绩效有何影响? 可能 的影响渠道是什么? 对这些问题的研究, 将有助于 找出提高小农水管护绩效的有效路径, 满足农户农 业生产经营需求,并为政府部门优化小农水治理机 制提供决策参考。

国内外学者对农户参与小农水管护意愿和行 为进行了广泛研究, 但对管护绩效的研究较少。处 于同一地域的农户享有共同的灌溉设施, 对小农水 供给具有相似的诉求, 通过长期交往建立的社会信 任能使分散的农户聚合, 并通过声誉机制对农户的 搭便车心理和行为进行约束, 有利于将微观农户个 体和宏观集体行动联合, 提升小农水管护绩效 ${ }^{[7]}$ 。 同时,公共产品属性使小农水管护成本较高,既需 要众多农户共同参与, 又需要组织提供支持来促进 管护合作。村组织的支持可以有效缓解农户参与 管护时的资金自投人压力,且能让农户感受到组织 对小农水治理的重视, 提升农户参与管护的心理预 期, 促进集体行动的实现, 从而提升管护绩效 ${ }^{\left[{ }^{[6]}\right.}$ 。现 有研究多把社会信任和组织支持独立对待, 较少将 两者联合起来分析，而组织支持可以为农户沟通交 流创造良好氛围,有利于农户社会信任水平的提 升,并最终作用于管护绩效。

针对以上不足, 本文尝试做出如下改进:第一, 在 Ostrom 的制度分析与发展框架(IAD Framework) 基础上,系统地梳理农户参与小农水管护绩效的影 响因素, 并纳人社会信任和组织支持变量以拓展现 有研究; 第二, 分析社会信任和组织支持对管护绩 效的影响, 并探究组织支持如何影响社会信任对管 护绩效的作用; 第三, 探究组织支持影响农户参与 小农水管护绩效的可能渠道,并提出相应政策建 议,为政府部门制定小农水管护政策提供理论与实 证支持。

\section{2 理论框架与研究假说}

Ostrom 的 IAD 框架用于阐释包含应用规则在 内的外生变量如何影响公共池塘资源的自主治理, 从而为资源使用者提供能够提升信任和合作的制 度设计方案与标准 ${ }^{[8]}$ 。IAD 框架可以用来分析和预
测不同情景中人的行为,包括公共池塘资源治理困 境中农户的行为。农户的认知系统是行动舞台的 核心,农户通过认知系统对自身所掌握的知识和信 息进行丰富和完善,并在此基础上对自身决策和行 为进行修正 ${ }^{[9]}$ 。作为公共资源管理的重要决定因 素, 社会信任内生、存在并镶嵌于农户的社会生活 之中 ${ }^{[10]}$,农户与其他成员建立的信任关系有助于他 们形成共同的行为准则和互惠的处事模式 ${ }^{[11]}$, 而感 受到组织支持的农户认为自己应负担较多责任, 更 愿意投人努力帮助组织实现目标 ${ }^{[6]}$, 最终影响管护 绩效。同时,良好的社区氛围能为农户合作创造有 利的条件,加之农户的个人特征和家庭情况对其管 护决策的影响,在 IAD 框架基础上,综合已有研究, 设计了本文的分析框架,如图 1 所示。

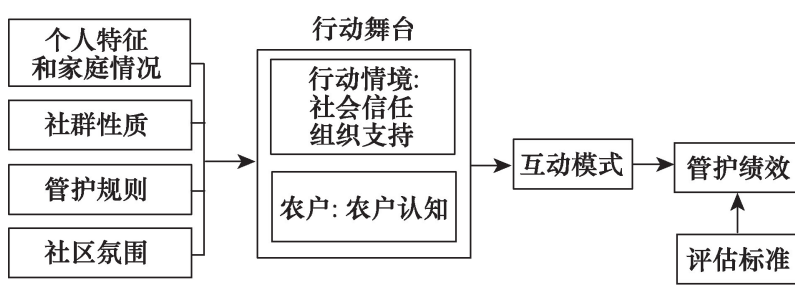

图 1 社会信任、组织支持对农户参与小农水管护 绩效影响的 IAD 分析框架

Figure 1 IAD framework of the impact of social trust and organizational support on the performance of farmers' participation in the management and maintenance of small-scale farmland water conservancy

\section{1 农户参与小农水管护绩效衡量}

绩效强调行为所应达到的有效结果以及实现 的最终目标,指组织为了达到目的而呈现于各层次 的有效输出 ${ }^{[12]}$ 。对于小农水而言,管护绩效由管护 结果来体现,表现为小农水管护所取得的成果或实 现的目标。作为典型的公共池塘资源, 小农水具有 使用的非排他性和资源获取的竞争性,不但需要在 管护过程中克服农户的搭便车行为,也就是供给问 题,还需要克服农户对资源过度使用造成的公地悲 剧现象,也就是占用问题 ${ }^{[13]}$ 。因此,对小农水管护绩 效的衡量可以从供给和占用角度进行衡量, 即小农 水的维护是否良好,灌溉用水的分配是否公平有 序, 灌溉用水的供应是否充足 ${ }^{[14]}$ 。值得注意的是,农 户参与管护是从自身农业生产经营的需求出发,并 受当地村干部或能人的引领, 在管护责任机制、保 
障机制和氛围引领机制等的约束下采取的集体行 动, 而作为管护结果的设施维护完好程度、用水分 配公平程度以及灌溉用水的充足程度是农户参与 管护集体行动以及管护机制的综合体现。鉴于灌 溉用水的充足程度受自然因素影响较大, 本研究选 取小农水的设施维护程度和灌溉用水分配的公平 程度作为绩效衡量指标。其中, 设施维护的完好程 度是农户在管护过程中投资和投劳程度的关键表 征,也是小农水管护机制是否有效运行的重要现实 反映,而作为农户有效行使灌溉权利的重要保障, 灌溉用水的公平分配则是分配机制合理以及农户 遵守灌溉规则的直接体现, 没有公正有序的灌溉资 源分配, 当地的灌溉水使用者几乎不会有持续的动 力为小农水的管护做贡献 ${ }^{[2]}$, 两者共同构成了农户 参与小农水管护绩效。在对绩效进行评估时, 既可 以遵循客观信息的非感知绩效模式, 又可以强调农 户主观判断的感知绩效模式 ${ }^{[15]}$ 。而作为以农户需求 为依据, 强调公共性、服务性、责任性和回应性等特 点的小农水, 以农户为评估主体展开管护绩效的评 价更有价值, 这是因为农户对管护绩效的感知是农 户是否愿意继续参与管护的重要因素, 且考虑到小 农水的管护主体多为当地农户, 促进农户积极参与 管护集体行动是提升小农水管护绩效的主要途 径。因此, 强调农户对小农水管护绩效的感知, 并 探索提升农户对管护绩效感知的重要因素, 是突破 管护集体行动困境, 提升小农水管护绩效的关键。 本研究通过农户对小农水的维护程度和灌溉用水 分配公平程度的感知来评估管护绩效,并在此基础 上探索影响管护绩效的因素。

\section{2 社会信任与农户参与小农水管护绩效}

社会信任被认为是基于普通共享规范的对网 络成员期望可靠性的感知和解释, 是社会资本的重 要组成部分。在一个共同体中, 信任水平越高, 成 员间合作的可能性就越大 ${ }^{[16]}$ 。一方面, 社会信任作 为农户在农村社区赖以生存的社会货币, 能够通过 建立内在约束机制的方式对农户行为进行制约, 可 以有效减少农户的搭便车等机会主义行为 ${ }^{[17]}$, 促进 管护集体行动的成功, 从而保障小农水的有效维 护。另一方面, 社会信任能有效促进农户之间的信 息沟通交流,减少农户之间的信息不对称情况,有
助于降低管护合作中的交易成本, 促进农户对灌溉 过程进行更有效的监督 ${ }^{\left[{ }^{[18}\right.}$, 保障自身的灌溉权利, 促 进灌溉用水分配的公平。根据以上分析, 本文提出 如下假说:

假说 1 : 社会信任正向影响农户参与小农水管 护绩效。

在农户参与小农水管护绩效分析的基础上,假 说 1 可以进一步细分为以下两个假说:

假说 1-1: 社会信任正向影响小农水利设施维 护程度。

假说 1-2:社会信任正向影响灌溉用水分配的 公平程度。

\section{3 组织支持与农户参与小农水管护绩效}

组织支持用以描述成员对组织是否重视他们 的贡献,并关心他们的福利待遇的总体感觉 ${ }^{[19]}$, 是农 户愿意在小农水管护过程中付出努力的关键因 素。组织支持理论认为,成员感知到的组织支持程 度较高时,他们就会通过承诺、努力和业绩等方式 做出互惠行为, 回报组织支持 ${ }^{[20,21]}$ 。感受到组织支 持的农户认为自己应当担负较多责任,他们将产生 积极的行为回报组织 ${ }^{[22]}$, 高水平的组织支持会使农 户表现出更多的有利于组织的态度和行为, 从而提 升整体绩效 ${ }^{[23]}$ 。研究表明, 组织支持由情感支持和 工具支持构成，情感支持会直接影响农户的心理结 果并激发整体心理潜能,感受到情感支持的农户会 做出互惠行为来回报组织, 即积极参与小农水管 护, 从而保障设施完好。另外,村组织为农户提供 的工具支持能促进农户更充分了解灌溉信息,增强 对灌溉过程的监督能力, 有利于灌溉用水的公平分 配。根据以上分析, 本文提出如下假说:

假说 2 : 组织支持正向影响农户参与小农水管 护绩效。

在农户参与小农水管护绩效分析的基础上,假 说 2 可以进一步细分为以下两个假说:

假说 2-1: 组织支持正向影响小农水利设施维 护程度。

假说 2-2: 组织支持正向影响灌溉用水分配的 公平程度。

\section{4 组织支持影响社会信任对管护绩效的作用}

社会信任与组织支持不是独立作用于农户参 
与小农水管护绩效,社会信任对管护绩效的作用会 受到组织支持的影响:一方面, 村组织对农户的支 持会使农户感知到被赞同和被尊重, 有助于满足农 户的社会需要和心理需要, 使农户与村组织之间产 生积极的情感纽带 ${ }^{[24,25]}$, 促进农户与村组织和其他 村民之间的交流合作并增强彼此的关系信任感; 另 一方面,农户从村组织获得的支持是组织认可农户 并愿意为其投人的积极对待,既能让农户感受到村 组织对小农水治理的重视, 提升农户对村组织的认 可程度 ${ }^{[26]}$, 激发农户参与管护的积极性, 促进小农水 的有效维护, 又能减少农户的信息搜寻成本, 充分 发挥农户在灌溉过程中的监督作用,保障灌溉用水 分配的公平。根据以上分析, 本文提出如下假说:

假说 3 : 组织支持可以增强社会信任对农户参 与小农水管护绩效的正向作用。

在农户参与小农水管护绩效分析的基础上,假 说 3 可以进一步细分为以下两个假说:

假说 3-1: 组织支持可以增强社会信任对小农 水利设施维护程度的正向作用。

假说 3-2: 组织支持可以增强社会信任对灌溉 用水分配公平程度的正向作用。

\section{3 数据来源、模型构建与变量定义}

\section{1 数据来源}

本文数据来源于课题组 2016 年 9 月- 11 月在 内蒙古和宁夏进行的实地调研。内蒙古和宁夏位
于黄河灌区中上游,气象干旱时有发生,农业生产 过程中对灌溉的依赖性较强,所选调研区域具有代 表性。为了保证问卷设计的合理和调查的质量,在 正式调研之前进行了预调研,并在此基础上对调查 程序和问卷内容进行了修改完善, 实地调研过程中 采用问卷调查与农户访谈相结合的方式对数据进 行收集。结合分层抽样和随机抽样,两个省份 40 个 行政村共 800 户农户被抽取,剔除缺失数据和有异 常值等农户问卷,最终获取有效问卷 774 份, 有效回 收率为 $96.75 \%$,样本农户的基本情况见表 1 。

(1)村庄基本特征。样本村庄多在产粮地区, 以农庄型村庄为主,社区型村庄较少。40个样本村 庄,其中 7 个村庄有小农水重点建设项目, 8 个村庄 为农业示范基地, 5 个村庄为贫困村。 40 个样本村 庄的平均人口规模约为 2094 人, 平均耕地面积约 $1006.53 \mathrm{hm}^{2}$, 人均耕地面积约为 $0.48 \mathrm{hm}^{2}$ 。村庄到 最近集市的平均距离为 $8.7 \mathrm{~km}$, 最远距离为 20 $\mathrm{km}$ 。样本村庄灌溉水源主要为黄河水, 灌溉方式主 要为渠灌, 渠道平均长度约为 $39 \mathrm{~km}$ 。

(2)农户基本特征。受访农户个体呈现如下特 征: 以男性为主, 占 $63.18 \%$; 以 46 55 岁和 56 65 岁 年龄段为主,分别占 $38.37 \%$ 和 $31.78 \%$; 以小学和初 中文化程度为主，二者合计占 $93.54 \%$ 。受访农户家 里有村干部的有 148 户; 家庭规模以 3 5 人的中等 规模为主, 占 $59.04 \%$; 家庭平均劳动力人数为 2.96

表 1 样本农户的个体特征及家庭特征统计性描述

Table 1 Statistical description of individual characteristics and family characteristics of the sample farmers

\begin{tabular}{|c|c|c|c|c|c|c|c|}
\hline \multicolumn{2}{|l|}{ 统计指标 } & \multirow{2}{*}{$\frac{\text { 频率 }}{489}$} & \multirow{2}{*}{$\begin{array}{c}\text { 比例 } / \% \\
63.18\end{array}$} & \multicolumn{2}{|l|}{ 统计指标 } & \multirow{2}{*}{$\frac{\text { 频率 }}{227}$} & \multirow{2}{*}{$\begin{array}{c}\text { 比例/\% } \\
29.33\end{array}$} \\
\hline 性别 & 男 & & & 家庭规模/人 & $<3$ & & \\
\hline & 女 & 285 & 36.82 & & $3 \sim 5$ & 457 & 59.04 \\
\hline \multirow[t]{5}{*}{ 年龄/岁 } & $\leqslant 35$ & 30 & 3.88 & & $6 \sim 8$ & 83 & 10.72 \\
\hline & $36 \sim 45$ & 117 & 15.12 & & $\geqslant 9$ & 7 & 0.91 \\
\hline & $46 \sim 55$ & 297 & 38.37 & 家庭耕地面积 $/ \mathrm{hm}^{2}$ & $\leqslant 1$ & 202 & 26.10 \\
\hline & $56 \sim 65$ & 246 & 31.78 & & $1 \sim 2$ & 225 & 29.07 \\
\hline & $\geqslant 66$ & 84 & 10.85 & & $2 \sim 3$ & 121 & 15.63 \\
\hline \multirow[t]{5}{*}{ 受教育程度 } & 小学及以下 & 417 & 53.88 & & $3 \sim 4$ & 102 & 13.18 \\
\hline & 初中 & 307 & 39.66 & & $>4$ & 124 & 16.02 \\
\hline & 高中或中专 & 46 & 5.94 & 家庭年收人/元 & $\leqslant 30000$ & 130 & 16.80 \\
\hline & 大专 & 2 & 0.26 & & $30001 \sim 60000$ & 163 & 21.06 \\
\hline & 本科及以上 & 2 & 0.26 & & $60001 \sim 90000$ & 150 & 19.38 \\
\hline \multirow[t]{2}{*}{ 家里是否有村干部 } & 是 & 148 & 19.12 & & $90001 \sim 120000$ & 140 & 18.09 \\
\hline & 否 & 626 & 80.88 & & $\geqslant 120001$ & 191 & 24.67 \\
\hline
\end{tabular}


人; 家庭耕地面积以 $\leqslant 1 \mathrm{hm}^{2}$ 和 1 $2 \mathrm{hm}^{2}$ 为主, 二者合 计占 $55.17 \%$; 家庭年收人处于 $30001 \sim 60000$ 元、 $\geqslant 120001$ 元的农户居多,分别占 $21.06 \%$ 和 $24.67 \%$, 样本农户基本情况如表 1 所示。样本农户情况与第 六次人口普查数据的相关信息接近, 可认为本次调 查的样本具有一定代表性。

\section{2 模型构建}

根据上文的分析和假说, 本研究建立的关系函 数如下:

$Y($ 管护绩效 $)=F($ 社会信任、组织支持、

个人特征和家庭情况、农户认知、 管护规则、社群性质、社区氛围） + 随机干扰项

被解释变量为农户参与小农水管护绩效, 衡量 指标为小农水利设施维护程度以及用水分配的公 平程度, 根据设施维护程度从 “损毁严重” 到 “很完 好”, 以及用水分配公平程度从“很不公平”到“很公 平”, 依次赋值为 $1 \sim 5$ 的整数。由于管护绩效是可以 按照高低顺序排列的有序多分类响应变量, 因此采 用Ordered Probit模型进行估计。该模型描述如下:

设管护绩效 $y$ 在 $\{1,2, \cdots, k\}$ 上取值 (本研究中 $k=5)$, 解释变量 $x_{1}, x_{2}, \cdots, x_{i}$ 为管护绩效影响因素 变量 (指标变量), 由于离散值作为被解释变量将带 来严重的异方差和不一致问题, 因此要将其转化为 连续变量 $y^{*}$ 。

假设存在无法直接观测的变量 $y^{*}$, 它是指标变 量 $x$ 的连续函数, 它与指标变量 $x_{i}$ 之间具有如下线 性关系:

$$
y^{*}=\beta_{0}+\beta_{1} x_{1}+\beta_{2} x_{2}+\cdots+\beta_{i} x_{i}=\beta^{\prime} x+\varepsilon
$$

该方程为 Ordered Probit模型的潜回归方程, 其 中 $\varepsilon$ 为随机扰动项, 服从正态分布, $\beta$ 为 $i \times 1$ 的向 量, 是待估参数。由于 $y^{*}$ 无法直接测量, 所以它必 须借由可观测到的 $y$ 来测量, 设 $\delta_{1}<\delta_{2}<\cdots<\delta_{k-1}$ 表 示未知的阈值参数 (分界点 cut point), 本研究中 $k=$ 5 , 所以存在 4 个阈值参数 $\delta_{1} 、 \delta_{2} 、 \delta_{3} 、 \delta_{4}$, 则 $y$ 和 $y^{*}$ 的关系如下:

$$
\begin{cases}y=1 & \left(\text { 当 } y^{*} \leqslant \delta_{1}\right. \text { 时 ) } \\ y=2 & \left(\text { 当 } \delta_{1}<y^{*} \leqslant \delta_{2}\right. \text { 时 ) } \\ y=3 & \left(\text { 当 } \delta_{2}<y^{*} \leqslant \delta_{3}\right. \text { 时 ) } \\ y=4 & \left(\text { 当 } \delta_{3}<y^{*} \leqslant \delta_{4}\right. \text { 时 ) } \\ y=5 & \left(\text { 当 } y^{*}>\delta_{4}\right. \text { 时) }\end{cases}
$$

因此,基于 IAD 框架的农户参与小农水管护绩 效影响因素的Ordered Probit模型可以表达如下：

$$
Y_{i}=c X_{i}+d F C_{i}+e R_{i}+f C C_{i}+g C A_{i}+\varepsilon_{i}
$$

式中 $Y_{i}$ 表示农户 $i$ 对参与小农水管护绩效的回答; $X_{i} 、 F C_{i} 、 R_{i} 、 C C_{i} 、 C A_{i}$ 为解释变量, 分别表示农户 个体特征及家庭情况、农户认知、管护规则、社群性 质以及社区氛围变量,这五类变量基本涵盖了 IAD 框架中可能影响农户参与小农水管护绩效的因素 ; $\varepsilon_{i}$ 为随机扰动项。在方程 (3) 的基础上引人 $S T_{i}$ (社 会信任) 和 $O S_{i}$ (组织支持)变量, 并通过估计方程 (4) 来探讨社会信任和组织支持对农户参与小农水 管护绩效的影响。

$$
Y_{i}=a S T_{i}+b O S_{i}+c X_{i}+d F C_{i}+e R_{i}+f C C_{i}+g C A_{i}+\varepsilon_{i}
$$

本研究重点关注式中的系数 $a$ 和 $b$, 通过其符号 来判断社会信任和组织支持对管护绩效的影响。

\section{3 变量定义}

变量定义及统计性描述见表 2 。

(1)农户参与小农水管护绩效 $(Y)$ 。农户参与 小农水管护绩效不但强调灌溉设施的供给绩效, 还 强调灌溉用水分配的秩序绩效。完好的灌溉设施 能减少水传递过程中的损耗,而公平的灌溉用水分 配能减少精英俘获现象, 两者共同作用, 为农户农 业生产经营提供有力保障。借鉴 $\mathrm{Lam}^{[14]}$ 的做法, 本 研究将农户参与小农水管护绩效划分为设施维护 程度和灌溉用水分配公平程度, 来自于受访农户对 调查问题“您所在的村组小型农田水利设施维护状 况如何?”以及“您所在的村组灌溉用水分配公平程 度如何?”的回答。当农民回答“损毁严重”一“很完 好”以及“很不公平”- “很公平”时, 依次赋值为 1 5 的整数。调查发现,认为小农水“比较完好”和“很 完好”的农户占 $76.87 \%$, 认为灌溉用水分配“比较公 平”和 “很公平”的农户占 $56.85 \%$ 。可能原因是, 内 蒙古和宁夏对农田灌溉较为重视, 政府投人大量资 金支持水利设施的建设和维护,并制定了相应的政 策对小农水治理给予指导, 促进了小农水的有效 管护。

(2) 社会信任变量 $(S T)$ 。社会信任决定着农户 愿意在什么程度上依赖他人建议参与管护 ${ }^{[27]}$, 鉴于 
表 2 Ordered Probit 模型中变量的定义及统计性描述

Table 2 Definitions and statistical descriptions of variables in Ordered Probit model

\begin{tabular}{|c|c|c|c|c|c|}
\hline 变量类别 & 变量名 & 均值 & 标准差 & 最小值 & 最大值 \\
\hline \multirow[t]{2}{*}{ 农户参与小农水管护绩效 } & 小农水利设施维护程度(intactness) & 3.851 & 0.872 & 1 & 5 \\
\hline & 灌溉用水分配公平程度 (fairness) & 3.442 & 1.075 & 1 & 5 \\
\hline \multirow[t]{3}{*}{ 社会信任 } & 对亲人的信任(relative) & 4.040 & 1.009 & 1 & 5 \\
\hline & 对邻居的信任(neighbor) & 3.540 & 0.841 & 1 & 5 \\
\hline & 对同村村民的信任(villager) & 3.424 & 0.893 & 1 & 5 \\
\hline \multirow[t]{5}{*}{ 组织支持 } & 从村组织获得的支持程度 (support) & 3.720 & 0.894 & 1 & 5 \\
\hline & 对您使用灌溉设施给予充分尊重 (respect) & 3.673 & 0.969 & 1 & 5 \\
\hline & 重视您在管护中所做的贡献(attention) & 3.217 & 0.834 & 1 & 5 \\
\hline & 为您提供良好的灌溉设施( facility) & 3.685 & 1.074 & 1 & 5 \\
\hline & 为您提供完善的灌溉信息 (information) & 4.221 & 0.794 & 1 & 5 \\
\hline \multirow{7}{*}{ 个体特征和家庭情况 } & 年龄 (age) & 53.795 & 9.991 & 19 & 83 \\
\hline & 文化程度(education) & 1.534 & 0.644 & 1 & 5 \\
\hline & 健康状况 (health) & 3.784 & 1.010 & 1 & 5 \\
\hline & 家中是否有村干部( cadre) & 0.191 & 0.394 & 0 & 1 \\
\hline & 家庭劳动力数 (labor) & 2.963 & 1.256 & 1 & 7 \\
\hline & 家庭耕地面积( land) & 2.547 & 2.113 & 0.07 & 16.67 \\
\hline & 家庭收人(income) & 8.436 & 5.414 & 0.15 & 59.00 \\
\hline \multirow[t]{3}{*}{ 农户认知 } & 灌溉水水价认知 (price) & 3.860 & 0.706 & 1 & 5 \\
\hline & 小农水对收人增加重要性认知 (increase) & 3.592 & 0.833 & 1 & 5 \\
\hline & 政府对小农水的投资力度认知 (investment) & 3.786 & 0.806 & 1 & 5 \\
\hline 管护规则 & 管护资金使用透明 (transparency) & 3.377 & 1.050 & 1 & 5 \\
\hline \multirow[t]{2}{*}{ 社群性质 } & 共用主要灌溉设施农户数( number) & 17.503 & 12.392 & 5 & 60 \\
\hline & 粮食面积占耕地面积之比( area ratio) & 0.718 & 0.355 & 0 & 1 \\
\hline \multirow[t]{3}{*}{ 社区氛围 } & 人际关系(relationship) & 3.850 & 0.694 & 1 & 5 \\
\hline & 社会风气(atmosphere) & 3.879 & 0.656 & 1 & 5 \\
\hline & 社区归属感( belonging) & 3.708 & 0.775 & 1 & 5 \\
\hline
\end{tabular}

社会信任与差序格局的人际关系结构有关联,中国 人社会信任群体中既有关系比较亲近的亲人,也有 与自己有拟亲属关系的外人,与自己愈近,关系愈 亲密,信任程度愈高 ${ }^{[2]}$ 。借鉴蔡起华等 ${ }^{[27]}$ 、何可等 ${ }^{[5]}$ 的研究,本文将社会信任分为特殊信任和一般信 任, 其中, 特殊信任选取了农户对亲人的信任,一般 信任选取了农户对邻居和同村村民的信任。需要 关注的是, 本研究的信任并非通常意义的理解, 而 是指农民在参与小农水管护时对他人所持有的一 种符合自身利益的理性行为预期或情感认同 ${ }^{[5]}$ 。在 调研时, 考虑到农民的理解能力与接受能力, 将上 述信任变量转化为如下问题: “我对亲人非常信任:
如果亲人参与小农水管护,我也会参与”、“我对邻 居非常信任: 如果邻居参与小农水管护, 我也会参 与”、“我对同村村民非常信任: 如果同村村民参与 小农水管护,我也会参与”。当农民回答“很不信 任”一“很信任”时, 依次赋值为 1 5 的整数。

(3) 组织支持变量 $(O S)$ 。组织支持是成员通过 组织对其奖励程度以及情感需求的满足程度发展 形成的组织是否关注自身福利, 以及具体的支持程 度的综合感知 ${ }^{[19]}$ 。借鉴 Eisenberger 等 ${ }^{[19]}$ 的研究, 本 文农户获得的组织支持来自于农户对调查问题“村 组织在您灌溉过程中给予的支持程度如何?”的回 答。由于组织支持是重点关注变量, 本文还根据凌 
文轻等 ${ }^{[29}$ 的研究将组织支持划分为情感支持及工具 支持, 并依据小农水管护具体情况, 设置了组织支 持的 4 个替代变量。其中, 情感支持包括“村组织对 您使用灌溉设施给予充分的尊重”、“村组织重视您 在小农水管护中所做的贡献”, 工具支持包括“村组 织为您提供良好的灌溉设施”、“村组织为您提供完 善的灌溉信息”。当农民回答“很不同意”一“很同 意”时, 依次赋值为 $1 \sim 5$ 的整数。

(4)农户个人特征和家庭情况变量 $(X)$ 。包括 被调查者性别, 男性赋值为 1 ,女性赋值为 0 ; 年龄, 以实际年龄 (周岁) 进行衡量; 文化程度, 小学及以 下赋值为 1 , 初中赋值为 2 , 高中或中专赋值为 3 , 大 专赋值为 4 , 本科及以上赋值为 5 ; 健康状况, “很 差”- “很健康” 依次赋值为 $1 \sim 5$ 的整数; 家中是否有 村干部, 有赋值为 1 , 没有赋值为 0 ; 家庭劳动力数, 用家庭实际劳动力人数 (人) 来衡量; 家庭耕地面 积, 用家庭实际耕地 (包括旱地和水田) 的总面积 $\left(\mathrm{hm}^{2}\right)$ 进行衡量; 家庭收人, 用家庭上一年的种养收 人、务工收人和其他收人之和(万元) 来衡量。

(5)农户认知变量 $(F C)$ 。包括农户对本村灌溉 用水水价的认知, “很低”- “很高” 依次赋值为 1 5 的整数; 小农水供给对家庭收人增加重要性的认 知, “完全不重要”- “很重要” 依次赋值为 1 5 的整 数; 政府对本村小农水投资力度的认知, “几乎不投 资”-“投资很多”依次赋值为 $1 \sim 5$ 的整数。

(6) 管护规则变量 $(R)$ 。包括小农水管护资金 使用透明程度, “很不透明”- “很透明” 依次赋值为 1 5 的整数; 小农水管护权责明晰程度, “很不明 晰”- “很明晰”依次赋值为 $1 \sim 5$ 的整数。

(7) 社群性质变量 $(C C)$ 。包括成员同质性与用 户群体规模, 由于成员同质性可以体现在多个层 面, 但 Poteet ${ }^{[30]}$ 提出利益诉求是否一致是决定集体 行动能否形成的最关键因素, 因此借鉴蔡荣 ${ }^{[3]}$ 的研 究,本文选取“农户粮食耕种面积占耕地面积之比” 作为成员同质性的代理变量, 用实际比例进行衡 量; 选取 “您与多少农户共用主要灌溉设施 (户)”来 表征用户群体规模, 用实际的农户户数进行衡量。

(8) 社区氛围变量 $(C A)$ 。包括农户所在社区人 与人之间的关系, 农户所在社区的社会风气, 以及 农户的社区归属感，“很差”一“很好” 依次赋值为
$1 \sim 5$ 的整数。

\section{4 多重共线性检验}

在进行模型估计之前, 考虑到影响农户参与小 农水管护绩效的变量之间可能存在内部相关,本研 究对各自变量进行多重共线性检验。通常情况下, 若 VIF $>3$, 表明各自变量之间有一定的多重共线 性。本研究以“对亲人的信任”作为被解释变量, 其 他变量作为解释变量进行估计。检验结果显示, VIF 值最高为 2.613 , 表明各自变量之间的共线性程 度处于合理范围, 满足 Ordered Probit模型要求。

\section{4 模型估计结果与解释}

\subsection{Ordered Probit 模型基准回归结果}

Ordered Probit模型基准回归结果见表 3 ,共包 含 4 个模型,其中模型 (1) 和模型 (2) 的被解释变量 为设施维护程度,模型 (3) 和模型 (4) 的被解释变量 为用水分配公平程度。模型 (1) 和模型 (3) 的解释 变量包括农户个体特征和家庭情况、农户认知、管 护规则、社群性质以及社区氛围这五类变量; 模型 (2) 和模型 (4) 分别在模型 (1) 和模型 (3) 基础上加 人了社会信任与组织支持变量。与模型 (1)相比, 模型 (2) 的伪 $R^{2}$ 由 0.3050 增至 0.3718 , 增幅为 $21.90 \%$, 说明社会信任和组织支持对设施维护程度 有重要影响; 与模型 (3) 相比, 模型 (4) 的伪 $R^{2}$ 由 0.2393 增至 0.2927 , 增幅为 $22.32 \%$, 说明社会信任 和组织支持对用水分配公平程度有重要影响。本 节对回归系数的解释基于模型(2)和模型(4)。

在表 3 的模型 (2)和模型 (4)中, 两个回归的结 果均显示社会信任和组织支持对农户参与小农水 管护绩效具有积极作用,假说 1 和假说 2 得到了证 实。具体而言:

(1)农户对亲人的信任 (relative) 在 10\%显著性 水平上正向影响设施维护程度,在 $1 \%$ 显著性水平 上正向影响用水分配公平程度。可能的解释是, 在 农村家庭生产经营的情况下,农户通过走访或送礼 方式与亲人保持密切联系,使得亲人成为农户相互 合作的重要纽带。农户与亲人之间的高度信任关 系, 使得农户行为更易受到亲人的影响, 亲人的管 护行为能有效促进农户参与管护, 从而保障小农水 完好。同时,亲人之间的密切交往降低了农户获取 


\section{表 3 Ordered Probit 模型基准回归结果}

Table 3 Benchmark regression results of Ordered Probit model

\begin{tabular}{|c|c|c|c|c|c|}
\hline & \multirow{2}{*}{ 变量 } & \multicolumn{2}{|c|}{ 设施维护程度 } & \multicolumn{2}{|c|}{ 用水分配公平程度 } \\
\hline & & 模型(1) & 模型(2) & 模型(3) & 模型(4) \\
\hline \multirow[t]{3}{*}{ 社会信任 } & relative & - & $\begin{array}{r}0.179^{*} \\
(0.094)\end{array}$ & - & $\begin{array}{l}0.239 * * * \\
(0.086)\end{array}$ \\
\hline & neighbor & - & $\begin{array}{l}0.343^{* * *} \\
(0.108)\end{array}$ & - & $\begin{array}{l}0.490^{\text {**** }} \\
(0.101)\end{array}$ \\
\hline & villager & - & $\begin{array}{l}0.287 * * * \\
(0.089)\end{array}$ & - & $\begin{array}{r}0.154^{*} \\
(0.084)\end{array}$ \\
\hline 组织支持 & support & - & $\begin{array}{l}0.467 * * * \\
(0.108)\end{array}$ & - & $\begin{array}{l}0.278^{* * *} \\
(0.096)\end{array}$ \\
\hline \multirow[t]{8}{*}{ 个体特征和家庭情况 } & gender & $\begin{array}{l}0.363 * * * \\
(0.104)\end{array}$ & $\begin{array}{c}0.105 \\
(0.112)\end{array}$ & $\begin{array}{l}0.446^{* * *} \\
(0.093)\end{array}$ & $\begin{array}{l}0.229 * * \\
(0.100)\end{array}$ \\
\hline & age & $\begin{array}{l}-0.001 \\
(0.004)\end{array}$ & $\begin{array}{c}0.001 \\
(0.004)\end{array}$ & $\begin{array}{c}-0.007^{*} \\
(0.004)\end{array}$ & $\begin{array}{l}-0.006 \\
(0.004)\end{array}$ \\
\hline & education & $\begin{array}{c}-0.105^{*} \\
(0.068)\end{array}$ & $\begin{array}{l}-0.086 \\
(0.070)\end{array}$ & $\begin{array}{l}-0.075 \\
(0.065)\end{array}$ & $\begin{array}{c}-0.067 \\
(0.069)\end{array}$ \\
\hline & health & $\begin{array}{c}-0.004 \\
(0.046)\end{array}$ & $\begin{array}{c}0.013 \\
(0.047)\end{array}$ & $\begin{array}{c}-0.029 \\
(0.042)\end{array}$ & $\begin{array}{l}-0.019 \\
(0.045)\end{array}$ \\
\hline & cadre & $\begin{array}{l}0.357 * * * \\
(0.123)\end{array}$ & $\begin{array}{c}0.217 * \\
(0.122)\end{array}$ & $\begin{array}{l}0.410^{* * *} \\
(0.131)\end{array}$ & $\begin{array}{l}0.268^{* *} \\
(0.132)\end{array}$ \\
\hline & labor & $\begin{array}{c}0.001 \\
(0.033)\end{array}$ & $\begin{array}{c}0.002 \\
(0.034)\end{array}$ & $\begin{array}{l}-0.017 \\
(0.035)\end{array}$ & $\begin{array}{l}-0.023 \\
(0.036)\end{array}$ \\
\hline & land & $\begin{array}{c}0.019 \\
(0.023)\end{array}$ & $\begin{array}{c}0.028 \\
(0.023)\end{array}$ & $\begin{array}{c}0.007 \\
(0.021)\end{array}$ & $\begin{array}{c}0.015 \\
(0.021)\end{array}$ \\
\hline & income & $\begin{array}{l}0.032 * * * \\
(0.010)\end{array}$ & $\begin{array}{r}0.017 * \\
(0.010)\end{array}$ & $\begin{array}{c}0.006 \\
(0.008)\end{array}$ & $\begin{array}{l}-0.008 \\
(0.008)\end{array}$ \\
\hline \multirow[t]{3}{*}{ 农户认知 } & price & $\begin{array}{l}-0.206^{* * *} \\
(0.070)\end{array}$ & $\begin{array}{l}-0.272 * * * \\
(0.073)\end{array}$ & $\begin{array}{l}0.201 * * * \\
(0.058)\end{array}$ & $\begin{array}{l}0.189 * * * \\
(0.062)\end{array}$ \\
\hline & increase & $\begin{array}{l}0.352^{* * * *} \\
(0.096)\end{array}$ & $\begin{array}{c}0.201 * * \\
(0.101)\end{array}$ & $\begin{array}{l}0.260^{* * * *} \\
(0.068)\end{array}$ & $\begin{array}{r}0.119^{*} \\
(0.072)\end{array}$ \\
\hline & investment & $\begin{array}{c}0.090 \\
(0.069)\end{array}$ & $\begin{array}{c}0.068 \\
(0.071)\end{array}$ & $\begin{array}{c}0.047 \\
(0.065)\end{array}$ & $\begin{array}{c}0.015 \\
(0.068)\end{array}$ \\
\hline \multirow[t]{2}{*}{ 管护规则 } & transparency & $\begin{array}{l}0.148^{* *} \\
(0.064)\end{array}$ & $\begin{array}{l}-0.002 \\
(0.074)\end{array}$ & $\begin{array}{l}0.266^{* * *} \\
(0.066)\end{array}$ & $\begin{array}{c}0.143^{* *} \\
(0.070)\end{array}$ \\
\hline & clarity & $\begin{array}{l}0.273^{* * * *} \\
(0.071)\end{array}$ & $\begin{array}{r}0.130^{*} \\
(0.072)\end{array}$ & $\begin{array}{l}0.190^{* * * *} \\
(0.073)\end{array}$ & $\begin{array}{c}0.069 \\
(0.078)\end{array}$ \\
\hline \multirow[t]{2}{*}{ 社群性质 } & number & $\begin{array}{l}-0.023^{* * * *} \\
(0.005)\end{array}$ & $\begin{array}{c}-0.010^{*} \\
(0.005)\end{array}$ & $\begin{array}{l}-0.015^{* * *} \\
(0.004)\end{array}$ & $\begin{array}{c}-0.001 \\
(0.005)\end{array}$ \\
\hline & area ratio & $\begin{array}{l}0.361 * * \\
(0.153)\end{array}$ & $\begin{array}{c}0.155 \\
(0.154)\end{array}$ & $\begin{array}{c}0.297 * * \\
(0.125)\end{array}$ & $\begin{array}{c}0.083 \\
(0.130)\end{array}$ \\
\hline \multirow[t]{3}{*}{ 社区氛围 } & relationship & $\begin{array}{c}0.183^{*} \\
(0.101)\end{array}$ & $\begin{array}{r}0.192 * \\
(0.104)\end{array}$ & $\begin{array}{r}0.162^{*} \\
(0.087)\end{array}$ & $\begin{array}{c}0.155 \\
(0.102)\end{array}$ \\
\hline & atmosphere & $\begin{array}{c}-0.019 \\
(0.073)\end{array}$ & $\begin{array}{c}-0.089 \\
(0.079)\end{array}$ & $\begin{array}{c}0.034 \\
(0.082)\end{array}$ & $\begin{array}{c}-0.017 \\
(0.087)\end{array}$ \\
\hline & belonging & $\begin{array}{c}0.144 * \\
(0.090)\end{array}$ & $\begin{array}{c}0.014 \\
(0.104)\end{array}$ & $\begin{array}{l}0.269^{* * *} \\
(0.094)\end{array}$ & $\begin{array}{c}0.173^{*} \\
(0.097)\end{array}$ \\
\hline 样本量 & & 774 & 774 & 774 & 774 \\
\hline 对数似然比 & & -629.6640 & -569.1580 & -812.7388 & -755.7728 \\
\hline 伪 $R^{2}$ & & 0.3050 & 0.3718 & 0.2393 & 0.2927 \\
\hline Prob $>$ chi 2 & & 0.0000 & 0.0000 & 0.0000 & 0.0000 \\
\hline
\end{tabular}

注: $* * * * * *$ 分别表示 $10 \% 、 5 \% 、 1 \%$ 的显著性水平; 括号中为稳健标准误。下同。 
信息的成本, 能促进农户更充分地了解灌溉状况, 对灌溉过程进行有效监督, 促进灌溉用水的公平 分配。

农户对邻居 (neighbor) 的信任在 1\%的显著性 水平上正向影响设施维护程度和用水分配公平程 度。可能的解释是, 当前中国农村社区熟人社会的 治理逻辑仍然存在, 以熟人信任建立起来的邻里关 系是中国传统社会关系的重要体现。与邻居高频 率的互动降低了农户达成一致行动的交易成本, 而 与邻居之间建立的信任关系使彼此的言行受到共 同准则的约束,更有利于集体行动的实现。农户对 邻居的信任程度越高, 越容易对管护集体行动形成 较高的预期,激发农户的管护行为, 且与邻居的良 好互动有利于农户获取完善的灌溉信息, 保障其灌 溉权利, 从而提升管护绩效。

农户对同村村民 (villager) 的信任在 1\%显著性 水平上正向影响设施维护程度, 在 $10 \%$ 显著性水平 上正向影响用水分配公平程度。可能的解释是, 生 活在同一社区的农户拥有共同的习俗、惯例和传统 等非正式制度约束, 且以地缘为基础建立的关系是 农户人际关系的重要组成部分。农户与同村村民 在灌溉方面有着共同的诉求, 同村村民的管护行为 能有效降低农户的搭便车心理和行为, 促进管护集 体行动, 从而保障灌溉设施完好。同时, 与同村村 民的交流能有效降低管护合作中的信息搜寻成本， 减少灌溉中的精英俘获等权利不对称现象, 保障灌 溉用水的公平分配。

(2)农户从村组织获得的支持 (support) 在 1\% 显著性水平上正向影响设施维护程度和用水分配 公平程度。可能的解释是, 小农水的建管护需要投 人大量物力、财力及人力, 超过了单个农户家庭的 承受范围, 而村组织的支持一方面可以减轻农户的 资金投人压力, 另一方面可以使农户感受到村组织 对小农水治理的重视, 提升农户的管护预期, 促进 管护集体行动的实现, 保障设施完好。同时, 村组 织可以对灌溉过程中的不公平行为进行约束或惩 罚, 保障农户有效行使灌溉权利, 实现灌溉用水的 分配公平。

(3) 在农户个体特征和家庭情况变量中,农户 的性别 (gender) 在 5\%显著性水平上正向影响用水
分配公平程度。可能的解释是, 村庄灌溉事务多由 男性主导, 男性更多地参与了灌溉用水规则的制定 和水量的分配。家中是否有村干部 (cadre) 分别在 $10 \%$ 和 $5 \%$ 显著性水平上正向影响设施维护程度和 用水分配公平程度。可能的解释是, 村干部在管护 过程中起带头示范作用, 且在用水分配过程中享有 更多的话语权。农户家庭收人(income) 在 $10 \%$ 显著 性水平上正向影响设施维护程度。可能的解释是, 收人较高的农户有较强的经济实力参与管护, 且容 易形成示范作用,能有效促进管护合作, 保障灌溉 设施完好。

(4)农户认知变量中, 农户对灌溉水价的认知 (price) 在 $1 \%$ 显著性水平上负向影响设施维护程 度,在 $1 \%$ 显著性水平上正向影响用水分配的公平 程度。可能的解释是, 较高的水价会削弱农户参与 管护的积极性,不利于管护工作的开展, 从而对设 施维护有负向影响。但对灌溉用水分配而言,一方 面较高的水价使农户更重视灌溉水的使用及灌溉 权利的维护,另一方面部分村庄将灌溉水的管理费 用计人水价, 导致水价较高,但管理费用的合理利 用保障了灌溉的公平有序。小农水对收人增加重 要性的认知 (increase) 在 5\%显著性水平上正向影响 设施维护程度,在 $10 \%$ 显著性水平上正向影响用水 分配公平程度。可能的解释是, 小农水对收人增加 越重要, 农户越倾向于投人资本和劳力参与管护, 从而提升管护绩效。

(5)管护规则变量中,管护资金使用透明 (transparency) 在 5\%显著性水平上正向影响用水分配公 平程度。可能的解释是,管护资金使用越透明,越 有利于农户充分行使监督权,从而促进管护资金的 有效使用,保障灌溉规则的有效实施, 实现灌溉用 水公平分配。管护权责明晰 (clarity) 在 10\%显著性 水平上正向影响设施维护程度。可能的解释是, 权 责明晰可以促进灌溉设施实现有人用、有人管的良 性循环。

(6)社群性质变量中,共用主要灌溉设施的农 户数量 $($ number $)$ 在 $10 \%$ 显著性水平上负向影响设 施维护程度。可能的解释是,管护集体行动中的搭 便车困境会随着成员个数的增加而加剧, 且搭便车 行为的存在削弱了农户参与管护的私人激励, 加速 
了小农水的老化失修进程。

(7)社区氛围变量中, 人际关系 (relationship) 在 $10 \%$ 显著性水平上正向影响设施维护程度。可能的 解释是, 良好的人际关系能有效促进农户与其他村 民的沟通交流,彼此建立的基于声誉的约束机制能 有效减少农户的搭便车行为,有利于管护集体行动 的实现, 从而保障设施完好。农户的社区归属感 (belonging) 在 $10 \%$ 显著性水平上正向影响用水分 配公平程度。可能的解释是, 不公平的用水分配会 打破社区秩序的平衡, 较强的社区归属感使农户愿 意为社区的良好运行负责, 从而愿意付出较多努力 促进灌溉用水的公平分配。

\section{2 组织支持的调节作用}

上述研究发现,社会信任和组织支持均对农户 参与小农水管护绩效有显著正向影响。鉴于组织 支持能为社会信任充分发挥作用创造良好的氛围， 值得思考的是,组织支持会影响社会信任在农户参 与小农水管护绩效中的作用吗? 对此, 本研究在方 程(4)的基础上加人社会信任和组织支持的交互项 来回答这个问题。

$$
\begin{aligned}
Y_{i}= & a S T_{i}+b O S_{i}+h S T_{i} \times O S_{i}+c X_{i} \\
& +d F C_{i}+e R_{i}+f C C_{i}+g C A_{i}+\varepsilon_{i}
\end{aligned}
$$

式中 $S T_{i} \times O S_{i}$ 为社会信任和组织支持的交互项; $h$ 为交互项系数。回归结果见表 4 ,共包含 6 个模型, 其中模型 (5)一模型 (7) 的被解释变量为设施维护 程度,并在模型 (2) 的基础上分别加人了组织支持 与社会信任各指标的交互项。模型 (8)一模型 (10) 的被解释变量为用水分配公平程度,并在模型 (4) 的基础上分别加人了组织支持与社会信任各指标 的交互项。由表 4 可知,交互项系数均为正,且组织 支持与农户对亲人和同村村民信任的交互项均显 著正向影响设施维护程度,组织支持与农户对邻居 和同村村民信任的交互项均显著正向影响用水分 配公平程度,假说 3 得到证实。可能的解释是,农户 与亲人、邻居和同村村民之间的信任能有效促进管 护合作,但村民自组织易受到关系亲疏的影响, 从 而影响管护合作关系的稳定性。而村组织的支持 能为管护集体行动创造良好的合作氛围并提供有 效的沟通平台,有利于农户共享信息并提升彼此的 信任感, 且能激发农户的组织公民行为, 促进管护 集体行动,从而保障设施完好。同时,村组织可以 对农户的灌溉行为进行监督和约束, 促进灌溉规则 的有效实施,实现用水公平分配。

表 4 组织支持对社会信任影响农户参与小农水管护绩效的调节作用

Table 4 The effect of organizational support moderating the effect of social trust on the performance of farmers' participation in the

\begin{tabular}{|c|c|c|c|c|c|c|c|}
\hline & \multirow{2}{*}{ 变量 } & \multicolumn{3}{|c|}{ 设施维护程度 } & \multicolumn{3}{|c|}{ 用水分配公平程度 } \\
\hline & & 模型 (5) & 模型(6) & 模型 (7) & 模型(8) & 模型(9) & 模型 (10) \\
\hline \multirow[t]{6}{*}{ 社会信任 } & relative & $0.267 * * *$ & $0.180^{*}$ & $0.194 * *$ & $0.260 * * *$ & $0.247 * * *$ & $0.255^{* * *}$ \\
\hline & & $(0.097)$ & $(0.094)$ & $(0.098)$ & $(0.083)$ & $(0.084)$ & $(0.086)$ \\
\hline & neighbor & $0.340 * * *$ & $0.348 * * *$ & $0.318 * * *$ & $0.488 * * *$ & $0.565^{* * *}$ & $0.459 * * *$ \\
\hline & & $(0.108)$ & $(0.104)$ & $(0.111)$ & $(0.102)$ & $(0.099)$ & $(0.100)$ \\
\hline & villager & $0.300 * * *$ & $0.285^{* * *}$ & $0.324 * * *$ & $0.159^{*}$ & $0.133 *$ & $0.201 * *$ \\
\hline & & $(0.090)$ & $(0.089)$ & $(0.089)$ & $(0.085)$ & $(0.085)$ & $(0.080)$ \\
\hline \multirow[t]{2}{*}{ 组织支持 } & support & $0.489 * * *$ & $0.469 * * *$ & $0.534 * * *$ & $0.279 * * *$ & $0.310^{* * *}$ & $0.355^{* * *}$ \\
\hline & & $(0.110)$ & $(0.109)$ & $(0.112)$ & $(0.096)$ & $(0.099)$ & $(0.094)$ \\
\hline \multirow[t]{6}{*}{ 交互项 } & relative $\times_{\text {support }}$ & $0.173 * * *$ & - & - & 0.056 & - & - \\
\hline & & $(0.064)$ & & & $(0.059)$ & & \\
\hline & neighbor $\times$ support & - & 0.011 & - & - & $0.187 * * *$ & - \\
\hline & & & $(0.072)$ & & & $(0.069)$ & \\
\hline & villager $\times$ support & - & - & $0.146^{*}$ & - & - & $0.186^{* *}$ \\
\hline & & & & $(0.076)$ & & & $(0.073)$ \\
\hline 样本量 & & 774 & 774 & 774 & 774 & 774 & 774 \\
\hline 对数似然比 & & -562.5134 & -569.1402 & -566.6134 & -755.0664 & -750.3137 & -750.9020 \\
\hline 伪 $R^{2}$ & & 0.3791 & 0.3718 & 0.3746 & 0.2933 & 0.2978 & 0.2972 \\
\hline Prob $>$ chi 2 & & 0.0000 & 0.0000 & 0.0000 & 0.0000 & 0.0000 & 0.0000 \\
\hline
\end{tabular}
management and maintenance of small-scale farmland water conservancy

注:其他变量均与表 3 中的模型 (2)和模型 (4)一致,限于篇幅未予汇报。 


\section{3 稳健性检验}

通常, 老年人由于年老体弱, 在从事农业生产 经营活动时劣势较为明显, 因此, 为了检验结果的
稳健性, 剔除了样本数据中 65 周岁以上的男性样本 和 60 岁以上的女性样本, 重新进行了 Ordered Probit

回归。如表 5 所示, 共包含 4 个模型, 分别与表 3 中

表 5 社会信任与组织支持影响农户参与小农水管护绩效的稳健性检验(剔除老年人样本)

Table 5 Robustness test of the effect of social trust and organizational support on the performance of farmers' participation in the management and maintenance of small-scale farmland water conservancy (Culling elderly samples)

\begin{tabular}{|c|c|c|c|c|c|}
\hline & \multirow{2}{*}{ 变量 } & \multicolumn{2}{|c|}{ 设施维护程度 } & \multicolumn{2}{|c|}{ 用水分配公平程度 } \\
\hline & & 模型(11) & 模型(12) & 模型 (13) & 模型(14) \\
\hline \multirow[t]{6}{*}{ 社会信任 } & relative & - & $0.168 *$ & - & $0.257 * * *$ \\
\hline & & & $(0.103)$ & & $(0.097)$ \\
\hline & neighbor & - & $0.362 * * *$ & - & $0.472 * * *$ \\
\hline & & & $(0.126)$ & & $(0.111)$ \\
\hline & villager & - & $0.219 * *$ & - & $0.168^{*}$ \\
\hline & & & $(0.107)$ & & $(0.097)$ \\
\hline \multirow[t]{2}{*}{ 组织支持 } & support & - & $0.419 * * *$ & - & $0.215^{*}$ \\
\hline & & & $(0.124)$ & & $(0.113)$ \\
\hline \multirow[t]{16}{*}{ 个体特征和家庭情况 } & gender & $0.333 * * *$ & 0.075 & $0.528 * * *$ & $0.312 * * *$ \\
\hline & & $(0.114)$ & $(0.122)$ & $(0.103)$ & $(0.112)$ \\
\hline & age & 0.001 & 0.003 & -0.009 & -0.007 \\
\hline & & $(0.006)$ & $(0.006)$ & $(0.006)$ & $(0.006)$ \\
\hline & education & -0.070 & -0.043 & -0.105 & -0.094 \\
\hline & & $(0.078)$ & $(0.082)$ & $(0.076)$ & $(0.081)$ \\
\hline & health & -0.025 & -0.010 & -0.028 & -0.012 \\
\hline & & $(0.052)$ & $(0.052)$ & $(0.048)$ & $(0.051)$ \\
\hline & cadre & $0.252 *$ & 0.157 & $0.530 * * *$ & $0.454 * * *$ \\
\hline & & $(0.136)$ & $(0.137)$ & $(0.148)$ & $(0.149)$ \\
\hline & labor & -0.027 & -0.014 & -0.048 & -0.045 \\
\hline & & $(0.039)$ & $(0.040)$ & $(0.040)$ & $(0.041)$ \\
\hline & land & 0.021 & 0.023 & 0.024 & 0.029 \\
\hline & & $(0.025)$ & $(0.025)$ & $(0.023)$ & $(0.024)$ \\
\hline & income & $0.031 * * *$ & $0.017^{*}$ & 0.008 & -0.006 \\
\hline & & $(0.010)$ & $(0.010)$ & $(0.008)$ & $(0.008)$ \\
\hline \multirow[t]{6}{*}{ 农户认知 } & price & $-0.233 * * *$ & $-0.279 * * *$ & $0.206 * * *$ & $0.210^{* * *}$ \\
\hline & & $(0.080)$ & $(0.082)$ & $(0.065)$ & $(0.070)$ \\
\hline & increase & $0.405 * * *$ & $0.244 * *$ & $0.265^{* * *}$ & 0.102 \\
\hline & & $(0.108)$ & $(0.114)$ & $(0.080)$ & $(0.084)$ \\
\hline & investment & 0.114 & 0.095 & 0.031 & 0.003 \\
\hline & & $(0.079)$ & $(0.081)$ & $(0.074)$ & $(0.078)$ \\
\hline \multirow[t]{4}{*}{ 管护规则 } & transparency & 0.114 & -0.016 & $0.275 * * *$ & $0.164 * *$ \\
\hline & & $(0.071)$ & $(0.080)$ & $(0.072)$ & $(0.078)$ \\
\hline & clarity & $0.233 * * *$ & 0.103 & $0.213 * * *$ & 0.103 \\
\hline & & $(0.080)$ & $(0.081)$ & $(0.082)$ & $(0.090)$ \\
\hline \multirow[t]{4}{*}{ 社群性质 } & number & $-0.026 * * *$ & $-0.012 * *$ & $-0.014 * * *$ & 0.002 \\
\hline & & $(0.005)$ & $(0.006)$ & $(0.005)$ & $(0.005)$ \\
\hline & area ratio & $0.438 * * *$ & 0.267 & $0.270 * *$ & 0.077 \\
\hline & & $(0.167)$ & $(0.166)$ & $(0.135)$ & $(0.141)$ \\
\hline \multirow[t]{6}{*}{ 社区氛围 } & relationship & 0.172 & $0.205^{*}$ & $0.129 *$ & 0.153 \\
\hline & & $(0.120)$ & $(0.121)$ & $(0.101)$ & $(0.118)$ \\
\hline & atmosphere & -0.031 & -0.099 & 0.003 & -0.048 \\
\hline & & $(0.089)$ & $(0.097)$ & $(0.096)$ & $(0.103)$ \\
\hline & belonging & 0.113 & -0.001 & $0.236 * *$ & 0.159 \\
\hline & & $(0.105)$ & $(0.120)$ & $(0.103)$ & $(0.106)$ \\
\hline 样本量 & & 623 & 623 & 623 & 623 \\
\hline 对数似然比 & & -505.4092 & -466.6046 & -649.5807 & -609.0236 \\
\hline 伪 $R^{2}$ & & 0.2901 & 0.3446 & 0.2379 & 0.2854 \\
\hline Prob $>$ chi 2 & & 0.0000 & 0.0000 & 0.0000 & 0.0000 \\
\hline
\end{tabular}


的 4 个模型相对应。结果表明, 表 5 的回归结果与 表 3 的结果基本一致。剔除老年人样本后,社会信 任和组织支持依然通过了显著性检验, 表明回归结 果较为稳健。

由于组织支持是本研究的重点关注变量, 为检 验实证结果的稳健性, 使用组织支持的替代变量估 计了组织支持对农户参与小农水管护绩效的影 响。如表 6 所示, 共包含 8 个模型, 其中, 模型 (15)一模型 (18)的被解释变量为设施维护程度,除 组织支持外, 其他变量均与模型 (2)一致。模型 (19) 一模型 (22) 的被解释变量为用水分配公平程 度, 除组织支持外, 其他变量均与模型 (4)一致。不 难发现,组织支持的替代变量均显著正向影响设施 维护程度和用水分配公平程度,与表3 结果一致, 由 此证实了组织支持能显著提高农户参与小农水管 护绩效,且实证分析结果较稳健。

\section{4 组织支持影响农户参与小农水管护绩效的渠道}

上述研究表明,组织支持对农户参与小农水管 护绩效有显著正向影响, 那么, 组织支持是通过什 么渠道发挥该影响作用的? 由于对村干部的认可 是农户愿意积极响应管护激励的关键因素,而对管 护制度的认可是小农水管护绩效有效实现的关键 保障, 因此从农户对村干部和管护制度的认可这两 方面对组织支持的影响渠道做进一步分析。

\subsection{1 组织支持影响农户对村千部的认可}

村组织的支持对农户参与小农水管护绩效有 显著促进作用,产生这种作用的可能路径是组织支 持增强了农户对村干部的认可,使农户更倾向于在 村干部的领导下参与管护。对此,本研究选取“农 户对村干部的认可程度 ( $1=$ 很不认可, $2=$ 比较不认 可, $3=$ 一般, $4=$ 比较认可, $5=$ 很认可)”作为被解释变 量进行 Ordered Probit模型回归。如表 7 所示, 模型 (23) 一模型 (27) 的被解释变量为农户对村干部的 认可, 解释变量分别为组织支持及其替代变量。结 果表明,组织支持及作为其替代变量的情感支持和 工具支持均能显著促进农户对村干部的认可。小 农水公共产品属性与农户家庭生产经营的私人产 品属性之间的冲突,使得村干部对农户的管护激励 通常与农户的实际需求不一致,而组织的情感支持 可以使农户感受到组织的认可和尊重,工具支持可 以减少农户自有资金的投人压力,从而促进农户做 出互惠行为来回报组织。在农村地区,组织对农户 的支持方式和支持力度通常是由村干部决策并执 行,这种方式能有效提升农户对村干部的认可程 度,促进农户对村干部的管护激励做出积极的行为 响应,从而提升小农水管护绩效。

\subsection{2 组织支持影响农户对管护制度的认可}

除了对村干部的认可外,另一个可能的渠道是 组织支持影响农户对管护制度的认可。村组织对

\section{表 6 组织支持影响农户参与小农水管护绩效的稳健性检验结果}

Table 6 Robustness test results of the effect of organizational support on the performance of farmers' participation in the management and maintenance of small-scale farmland water conservancy

\begin{tabular}{|c|c|c|c|c|c|c|c|c|c|}
\hline & \multirow{2}{*}{ 变量 } & \multicolumn{4}{|c|}{ 设施维护程度 } & \multicolumn{4}{|c|}{ 用水分配公平程度 } \\
\hline & & 模型 (15) & 模型(16) & 模型(17) & 模型(18) & 模型(19) & 模型(20) & 模型(21) & 模型(22) \\
\hline \multirow{7}{*}{$\begin{array}{l}\text { 组织 } \\
\text { 支持 }\end{array}$} & respect & $0.122 * *$ & - & - & - & $0.114 * *$ & - & - & - \\
\hline & & $(0.057)$ & & & & $(0.050)$ & & & \\
\hline & attention & - & $0.230 * * *$ & - & - & - & $0.114 * *$ & - & - \\
\hline & & & $(0.068)$ & & & & $(0.058)$ & & \\
\hline & & & & $(0.066)$ & & & & $(0.061)$ & \\
\hline & information & - & - & - & $0.314 * * *$ & - & - & - & $0.354 * * *$ \\
\hline & & & & & $(0.082)$ & & & & $(0.087)$ \\
\hline \multicolumn{2}{|c|}{ 样本量 } & 774 & 774 & 774 & 774 & 774 & 774 & 774 & 774 \\
\hline \multicolumn{2}{|c|}{ 对数似然比 } & -585.8289 & -581.3829 & -585.5059 & -577.5874 & -760.6060 & -761.4415 & -754.2833 & -748.3100 \\
\hline \multicolumn{2}{|l|}{ 伪 $R^{2}$} & 0.3534 & 0.3583 & 0.3537 & 0.3625 & 0.2881 & 0.2873 & 0.2940 & 0.2996 \\
\hline
\end{tabular}

注: 除组织支持外,其他变量均与表 3 中的模型(2)和模型(4)一致,限于篇幅未予汇报。 
表 7 组织支持影响农户对村干部认可的估计结果

Table 7 Estimated results of the influences of organizational support on farmers' approval of village cadres

\begin{tabular}{|c|c|c|c|c|c|c|}
\hline & 变量 & 模型(23) & 模型(24) & 模型(25) & 模型(26) & 模型(27) \\
\hline \multirow[t]{5}{*}{ 组织支持 } & support & $\begin{array}{l}0.301 * * * \\
(0.073)\end{array}$ & - & - & - & - \\
\hline & respect & - & $\begin{array}{l}0.204 * * * \\
(0.043)\end{array}$ & - & - & - \\
\hline & attention & - & - & $\begin{array}{l}0.167 * * * \\
(0.056)\end{array}$ & - & - \\
\hline & facility & - & - & - & $\begin{array}{r}0.103 * \\
(0.053)\end{array}$ & - \\
\hline & information & - & - & - & - & $\begin{array}{c}0.143^{* *} \\
(0.062)\end{array}$ \\
\hline 样本量 & & 774 & 774 & 774 & 774 & 774 \\
\hline 对数似然比 & & -1083.7373 & -1082.7329 & -1088.6232 & -1091.7871 & -1090.9023 \\
\hline 伪 $R^{2}$ & & 0.0530 & 0.0539 & 0.0487 & 0.0460 & 0.0467 \\
\hline Prob $>$ chi 2 & & 0.0000 & 0.0000 & 0.0000 & 0.0000 & 0.0000 \\
\hline
\end{tabular}

农户的支持通常是在制度的约束下展开, 获得组织 支持的农户更倾向于相信制度的合理性和有效性， 更愿意在小农水管护中做出合作行为。对此,本研 究选取了“农户对本村管护制度的认可程度 $(1=$ 很 不认可, $2=$ 比较不认可, $3=$ 一般, $4=$ 比较认可, $5=$ 很 认可)”作为被解释变量进行 Ordered Probit 模型回 归。如表 8 所示, 模型 (28)一模型 (32)的被解释变 量为农户对管护制度的认可, 解释变量分别为组织 支持及其替代变量。结果表明, 组织支持及作为其 替代变量的情感支持和工具支持均能显著促进农 户对管护制度的认可。组织支持有助于农户对管
护制度形成一种稳定的心理预期,农户对管护制度 越认可,对自身获得的福利期望越高,越倾向于参 与管护合作,促进管护绩效的提升。

\section{5 主要结论与政策建议}

\section{1 主要结论}

本研究在 IAD 框架基础上分析了社会信任和 组织支持对农户参与小农水管护绩效的影响。研 究结果表明:

(1) 在 IAD 框架下,农户参与小农水管护绩效 受个体特征和家庭情况、农户认知、管护规则、社群 性质以及社区氛围等变量的影响,其中农户家中是

表 8 组织支持影响农户对管护制度认可的估计结果

Table 8 Estimated results of the influences of organizational support on farmers' approval of management and maintenance institution

\begin{tabular}{|c|c|c|c|c|c|c|}
\hline & 变量 & 模型(28) & 模型(29) & 模型(30) & 模型(31) & 模型(32) \\
\hline \multirow[t]{5}{*}{ 组织支持 } & support & $\begin{array}{l}0.179 * * \\
(0.074)\end{array}$ & - & - & - & - \\
\hline & respect & - & $\begin{array}{c}0.113 * * \\
(0.049)\end{array}$ & - & - & - \\
\hline & attention & - & - & $\begin{array}{l}0.210^{* * *} \\
(0.061)\end{array}$ & - & - \\
\hline & facility & - & - & - & $\begin{array}{l}0.213 * * * \\
(0.057)\end{array}$ & - \\
\hline & information & - & - & - & - & $\begin{array}{c}0.130 * * \\
(0.066)\end{array}$ \\
\hline 样本量 & & 774 & 774 & 774 & 774 & 774 \\
\hline 对数似然比 & & -775.1375 & -775.3096 & -770.9955 & -770.4806 & -776.1975 \\
\hline 伪 $R^{2}$ & & 0.0772 & 0.0770 & 0.0822 & 0.0828 & 0.0760 \\
\hline Prob $>$ chi 2 & & 0.0000 & 0.0000 & 0.0000 & 0.0000 & 0.0000 \\
\hline
\end{tabular}


否有村干部、家庭收人、对灌溉水价的认知、对小农 水对收人重要性的认知、管护权责明晰程度、共用 主要灌溉设施的农户数量以及农户的人际关系显 著影响设施维护程度, 而性别、家中是否有村干部、 农户对水价的认知、对小农水对收人重要性的认 知、管护资金使用透明程度和农户的社区归属感显 著影响用水分配公平程度;

(2)农户对亲人、邻居和同村村民的信任, 以及 农户从村组织获得的支持均可以显著促进农户参 与小农水管护绩效的提升;

(3)组织支持可以增强社会信任对农户参与小 农水管护绩效的正向影响,其中,组织支持能显著 增强农户对亲人和同村村民的信任在设施维护中 的正向作用, 并能显著增强农户对邻居和同村村民 信任在用水分配公平中的正向作用;

(4)农户受到的组织支持及作为其替代变量的 情感支持和工具支持主要通过两个渠道发挥作用， 一是影响农户对村干部的认可, 二是影响农户对管 护制度的认可。

\section{2 政策建议}

本研究不仅验证了社会信任和组织支持对农 户参与小农水管护绩效的影响,还拓展分析了组织 支持如何影响社会信任在农户参与小农水管护绩 效中的作用。促进农户社会信任水平的提升, 并在 此基础上为农户提供有效的组织支持, 可能是提高 农户参与小农水管护绩效的一个新途径。具体而言：

(1) 为农户参与小农水管护合作提供良好的平 台并营造融洽的氛围, 促进农户之间的沟通交流并 提高彼此的关系信任感,减少农户在管护合作中的 搭便车心理和行为,促进小农水管护绩效的提升;

(2)增强组织对农户的支持力度, 为农户提供 尊重、重视和关心等情感支持,并为农户提供必要 的设备、资讯和培训等工具支持, 提高农户对村组 织的认可程度,激发农户参与小农水管护的积极性;

(3)积极推行小农水管护的村民自治模式,完 善农户对灌溉的需求表达机制和参与小农水管护 的决策机制, 提升农户参与小农水管护的整体水 平, 促进灌溉设施有人用、有人管良性循环的实现。

本文调研区域为内蒙古和宁夏, 虽然两省政府 在水利设施建管护方面较为重视,但小农水管护过
程中正式制度发挥的作用仍然较小,农户对乡村传 统的社会关系依赖较强,在此基础上建立的社会信 任有助于管护合作行为的达成, 而组织支持则有助 于激发农户对管护激励采取积极的行为响应,从而 提升管护绩效。但必须看到,本研究仍然存在一些 不足。本文试图充分探讨组织支持对农户参与小 农水管护绩效影响的可能渠道,但研究仍然不够全 面。鉴于关系网络在缓解各利益主体之间冲突、降 低管护合作中交易成本和道德风险的重要作用,本 文仍可以从其他视角进行深人研究。

\section{参考文献(References) :}

[1] Sinyolo S, Mudhara M, Wale E. The impact of smallholder irrigation on household welfare: the case of Tugela Ferry irrigation scheme in Kwazulu-Natal, South Africa[J]. Water SA, 2014, 40(1): $145-156$.

[2] Ostrom E. Governing the Commons: The Evolution of Institutions for Collective Action[M]. Cambridge: Cambridge University Press, 1990.

[3] Lam W F, Ostrom E. Analyzing the dynamic complexity of development interventions: lessons from an irrigation experiment in Nepal [J]. Policy Sciences, 2010, 43(1): 1-25.

[4] Ostrom E. Analyzing collective action[J]. Agricultural Economics, 2010, 41(S1): 155-166.

[5] 何可, 张俊䆦, 张露, 等. 人际信任、制度信任与农民环境治理参 与意愿一以农业废弃物资源化为例[J]. 管理世界, 2015, (5): 7588. [He K, Zhang J B, Zhang L, et al. Interpersonal trust, institutional trust and farmers' willingness to participate in environmental governance: based on the example of agricultural waste recycling[J]. Management World, 2015, (5): 75-88. ]

[6] 杨阳, 周玉玺, 周霞. 差序氛围、组织支持与农户合作意愿-基于 小型农田水利建管护的调查[J]. 南京农业大学学报(社会科学 版), 2015, 15(4): 87-97. [Yang Y, Zhou Y X, Zhou X. Differential atmosphere, organizational support, and willingness of farmers' cooperation: a survey based on construction, administration and maintenance of small scale conservancy facilities[J]. Journal of Nanjing Agricultural University (Social Sciences Edition), 2015, 15 (4): 87-97. ]

[7] Ostrom E. Self-organization and social capital[J]. Industrial and Corporate Change, 1995, 4(1): 131-159.

[8] Poteete A R, Janssen M A, Ostrom E. Working Together: Collective Action, the Commons, and Multiple Methods in Practice[M]. Princeton: Princeton University Press, 2010. 
[9] 何凌霄, 张忠根, 南永清, 等. 制度规则与干群关系: 破解农村基 础设施管护行动的困境-基于 IAD 框架的农户管护意愿研究 [J. 农业经济问题, 2017, 38(1): 9-21. [He L X, Zhang Z G, Nan Y Q, et al. Institutional rules and cadre-farmer relationship: solve the dilemma in rural infrastructures' maintenance action[J]. Issues in Agricultural Economy, 2017, 38(1): 9-21. ]

[10] Bouma J, Bulte E, Soest D V. Trust and cooperation: social capital and community resource management[J]. Journal of Environmental Economics \& Management, 2008, 56(2): 155-166.

[11] 埃莉诺-奥斯特罗姆, 龙虎. 社会资本: 流行的狂热抑或基本的 概念?[J]. 经济社会体制比较, 2003, (2): 26-34. [Ostrom E, Long H. Social trust: popular mania or basic concept? [J]. Comparative Economic \& Social Systems, 2003, (2): 26-34. ]

[12] 陈一恒. 村民民主参与行为与村庄公共治理绩效研究 [D]. 武 汉: 华中农业大学, 2012. [Chen Y H. Research about Villagers' Democratic Participation and Village Public Governance Performance[D]. Wuhan: Huazhong Agricultural University, 2012. ]

[13] Ostrom E, Gardner R, Walker J. Rules Games and Common-Pool Resources[M]. Michigan: University of Michigan Press, 1993.

[14] Lam W F. Institutions, Engineering Infrastructure, and Performance in the Governance and Management of Irrigation Systems: The Case of Nepal[D]. Bloomington: Indiana University, 1994.

[15] 范柏乃, 金洁. 公共服务供给对公共服务感知绩效的影响机 理-政府形象的中介作用与公众参与的调节效应[J]. 管理世 界, 2016, (10): 50-61. [Fan B N, Jin J. The impact of public service delivery on perceived public service performance: the mediating role of government image and the moderating role of public participation[J]. Management World, 2016, (10): 50-61. ]

[16] Putnam R D. Making Democracy Work: Civic Traditions in Modern Italy[M]. Princeton: Princeton University Press, 1993.

[17] Herb S, Hartmann E. Opportunism risk in service triads: a social capital perspective[J]. International Journal of Physical Distribution \& Logistics Management, 2014, 44(3): 242-256.

[18] Nooteboom, B. Trust: Forms, Foundations, Functions, Failures and Figures[M]. Cheltenham: Edward Elgar Publishing, 2002.

[19] Eisenberger R, Huntington R, Hutchison S, et al. Perceived organizational support[J]. Journal of Applied Psychology, 1986, 71(3): 500-507.

[20] Eisenberger R, Stinglhamber F, Vandenberghe C, et al. Perceived supervisor support: contributions to perceived organizational support and employee retention[J]. Journal of Applied Psychology, 2002, 87(3): 565-573.

[21] Chen Z, Eisenberger R, Johnson K M, et al. Perceived organizational support and extra-role performance: which leads to which? [J]. The Journal of Social Psychology, 2009, 149(1): 119-124.
[22] 黄俊, 吴隆增, 朱磊. CEO 变革型领导行为对中层管理者工作 绩效和工作满意度的影响: 组织支持知觉和价值观的作用 [J]. 心理科学, 2012, 35(6): 1445-1452. [Huang J, Wu L Z, Zhu L. The impact of CEO transformational leadership behavior on middle managers' job performance and job satisfaction: the roles of organizational support perception and values[J]. Journal of Psychological Science, 2012, 35(6): 1445-1452. ]

[23] Chong H, White R, Prybutok V. Relationship among organizational support, at implementation, and performance[J]. Industrial Management \& Data Systems, 2001, 101(6): 273-280.

[24] 许百华, 张兴国. 组织支持感研究进展[J]. 应用心理学, 2005, 11 (4): 325-329. [Xu B H, Zhang X G. Recent development in research on perceived organizational support[J]. Chinese Journal of Applied Psychology, 2005, 11(4): 325-329. ]

[25] Newman A, Thanacoody R, Hui W. The effects of perceived organizational support, perceived supervisor support and intra-organizational network resources on turnover intentions: a study of Chinese employees in multinational enterprises[J]. Personnel Review, 2012, 41(1): 56-72.

[26] Stamper C L, Dyne L V. Work status and organizational citizenship behavior: a field study of restaurant employees[J]. Journal of Organizational Behavior, 2001, 22(5): 517-536.

[27] 蔡起华, 朱玉春. 社会信任、关系网络与农户参与农村公共产品 供给[J]. 中国农村经济, 2015, (7): 57-69. [Cai Q H, Zhu Y C. Social trust, relationship network and farmers' participation in the supply of rural public goods[J]. Chinese Rural Economy, 2015, (7): 57-69. ]

[28] 牛喜霞, 汤晓峰. 农村社区社会资本的结构及影响因素分析[J]. 湖南师范大学社会科学学报, 2013, 42(4): 66-77. [Niu X X, Tang X F. Analysing the structure and influencing factors of rural community social capital[J]. Journal of Social Science of Hunan Normal University, 2013, 42(4): 66-77. ]

[29] 凌文轻, 张治灿, 方俐洛. 中国职工组织承诺研究[J]. 中国社会 科学, 2001, (2): 90-102. [Ling W Q, Zhang Z C, Fang L L. A study of the organizational commitment of Chinese employees[J]. Social Sciences in China, 2001, (2): 90-102. ]

[30] Poteete A R, Ostrom E. Heterogeneity, group size and collective action: the role of institutions in forest management[J]. Development and Change, 2004, 35(3): 435-461.

[31] 蔡荣. 管护效果及投资意愿: 小型农田水利设施合作供给困境 分析[J]. 南京农业大学学报(社会科学版), 2015, 15(4): 78-86. [Cai R. Maintaining effect and funding willingness: empirical analysis on collective supply willingness of farmland irrigation canals in rural community[J]. Journal of Nanjing Agricultural University (Social Sciences Edition), 2015, 15(4): 78-86. ] 


\title{
Influence of social trust and organizational support on the performance of farmers' participation in the management and maintenance of small-scale farmland water conservancy
}

\author{
YANG Liu, ZHU Yuchun, REN Yang \\ (College of Economics and Management, Northwest A \& F University, Yangling 712100, China)
}

\begin{abstract}
Because the governmental governance model of small-scale farmland water conservancy cannot fully meet the actual needs of farmers' agricultural production and management, farmers' participation in the management and maintenance has become the key to break the governance dilemma. Based on the IAD theoretical framework, this paper discussed the influence of farmers' social trust and organizational support on the performance of farmers' participation in the management and maintenance of small-scale farmland water conservancy theoretically. Then an Ordered Probit model was employed using 774 household surveys collected from Inner Mongolia and Ningxia. We conclude that farmers' social trust and organizational support positively the performance of farmers' participation in the management and maintenance of small-scale farmland water conservancy. To further verify the research conclusion, we establish a robustness test by culling older adults from the whole sample; the result is that this conclusion remained true. Apart from this aspect, organizational support could positively enhance the influence of social trust on the performance of farmers' participation in the management and maintenance of small-scale farmland water conservancy. Also, organizational support could affect the performance by affecting farmers' approval of village cadres and systems of management and maintenance. This study offers the government a policy enlightenment that, through promoting communication between farmers and their sense of social trust and enhancing organization support of village to farmers, it effectively the performance of farmers' participation in the management and maintenance of small-scale farmland water conservancy.
\end{abstract}

Key words: social trust; organizational support; small-scale farmland water conservancy; performance of management and maintenance; Ordered Probit model; Inner Mongolia; Ningxia 